Anna Babicka-Wirkus

https://doi.org/10.26881/pwe.2019.47.03

ORCID: 0000-0002-1292-7351

Akademia Pomorska w Shupsku

ankababicka@gmail.com

\title{
Style adaptacji uczniów do szkoły. Inspiracje dla nauczycieli wczesnej edukacji
}

\section{Summary}

\section{Styles of students adaptation to school. Inspirations for early childhood teachers}

The paper presents the issue of students adaptation to school life and shows its importance for the practice of early education teachers. In the text, school is defined as an institution which strives to subjugate the subjects operating within it while, paradoxically, giving them conditions for resisting the imposed rigours. While trying to deal with this complex reality, students have developed three main styles of adapting to its conditions. These include the following: insider, outsider, and subsider style. The first one is based on conformist actions. Outsiders engage in resistance behaviors which lead to their marginalization and even premature abandonment of the educational path. Subsiders are the ones who are able to resist and transform the dominant reality by acting in a space determined by the dominant culture while, at the same time, crossing the set boundaries.

Keywords: insiders, outsiders, subsiders, styles of adaptation, school, resistance

Słowa kluczowe: insiderzy, outsiderzy, subwersiderzy, style adaptacji, szkoła, opór

\section{Wprowadzenie}

Celem artykułu jest analiza sposobów adaptacji ${ }^{1}$ uczniów do rzeczywistości instytucji edukacyjnej. Zapoznanie się ze specyfiką tych stylów jest istotne przede wszystkim dla nauczycieli przedszkolnych i wczesnoszkolnych oraz dla adeptów tej profesji. Podejmowane przez nauczycieli wczesnej edukacji działania i sposoby organizacji środowiska wychowawczo-edukacyjnego mają znaczenie w konstruowaniu przez uczniów indywidualnych stylów adaptacji, które będą stosować na późniejszych etapach instytucjonalnego kształcenia. $\mathrm{Na}$ wczesnych poziomach edukacji dzieci są przygotowywane do życia w szkole. Znajomość i podporządkowanie się regułom szkoły pomagają przetrwać wyższe poziomy edukacji, ale także zniewalają dziecko i ograniczają jego podmiotowość. Dlatego też nauczyciele wczesnej edukacji powinni być szczególnie wrażliwi na zapewnienie warunków do rozwijania się samodzielnie myślącego i działającego ucznia, który będzie odważnie podejmował działania o(d)porowe nie tylko w szkole, ale również w środowisku pozaszkolnym.

1 Przyjmuję rozumienie adaptacji za Robertem Mertonem (2002). 
W artykule zaprezentowałam sposoby adaptowania się uczniów do szkoły, którą ujmuję przez pryzmat jej instytucjonalnego charakteru. Prowadzone analizy uwzględniają aspekt istnienia kultury oporu jako integralnej części kultury szkoły. Omawiane style adaptacji uczniów zostały opracowane na podstawie moich badań codzienności szkoły (Babicka-Wirkus 2018a, 2018b) oraz analizy literatury z zakresu problematyki oporu szkolnego i społecznego (Willis 1977; Scott 1985; McLaren 1999, 2015; Bilińska-Suchanek 2003). Wyróżniając style adaptacji uczniów do kultury szkoły, wzięłam pod uwagę głównie specyfikę ich uczestnictwa w wielowymiarowej kulturze oporu. Warto podkreślić, że każdy z tych stylów jest ważny dla swoistości i dynamiki życia szkoły. Są to style czyste, które w opisanej formie rzadko występują w codzienności szkoły. Zazwyczaj mamy w niej do czynienia z uczniami przejawiającymi połączenia poszczególnych sposobów adaptacji, w których jeden z typów jest dominujący.

\section{(Nie)wywrotowa kultura szkoły}

Szkoła w dyskursie publicznym i naukowym jest zazwyczaj prezentowana w kontekście determinującej jej specyfikę kultury dominującej. Istnienie kultury oporu jest w tych analizach przeważnie pomijane, co niewątpliwie prowadzi do niedostrzegania jej znaczenia dla kształtu struktury norm, wartości, ról i pozycji społecznych w tej instytucji. Kultura oparta na sprzeciwie nie stanowi ukrytego wymiaru rzeczywistości szkoły, lecz jest niezbędnym komponentem kształtującym jej rzeczywistość. Definiuję ją jako strukturę „,... działań wynikających z poglądów, postaw i relacji bazujących na niezgodzie wobec dominującego porządku. Jest antystrukturą wyłaniającą się z opozycji do dominującej struktury szkoły, czyli obowiązującego porządku aksjonormatywnego, wyznaczającego specyficzny układ relacji między poszczególnymi jej elementami” (Babicka-Wirkus 2019: 12). Stanowi ona przestrzeń, w której głos zdominowanych (uczniów) może być słyszalny, nabierać znaczenia i wprowadzać odmienne sposoby rozumienia i interpretacji w uprzywilejowany w szkole dyskurs normatywny. Jest to pole, w którym „oręż słabych” - jak określa opór James C. Scott (1985) - ma możliwość stania się narzędziem zmiany poprzez kontestowanie utrwalonych sposobów działania i myślenia.

Specyfika swoistej broni słabszych, uciśnionych nie sprowadza się do aktów zbiorowych, lecz często przejawia się w postaci działań indywidualnych lub typowych dla mało licznych grup. Nie przybiera ona formy otwartego nieposłuszeństwa wobec władzy (nauczycieli, dyrekcji), lecz staje się elementem codzienności i rutyny, który jest niedostrzegalny dla reprezentantów porządku szkolnego. Wyrazem tego typu działań są: ociąganie się, udawanie niepojętnego, prezentowanie fałszywej pokory, leżenie na ławce, symulowanie itp. (McLaren 1999; Kuligowski 2012; Babicka-Wirkus 2018a). Działania te nie wymagają planowania ani koordynacji. Zazwyczaj są spontaniczną reakcją na konkretną sytuację. W celu rozprzestrzeniania tego typu aktywności uczniowie wykorzystują nieformalne sieci i mechanizm zrozumienia bez słów (Scott 1985: XVI). 
Działania o charakterze o(d)porowym i wywrotowym, podjęte w ramach wyznaczonych przez kulturę dominującą i zdefiniowany przez nią public transcript, wprowadzają do niego elementy hidden transcript, który jest tworzony poza oficjalną sceną (Scott 1985). Dyskurs ukryty, zakulisowy nie podlega bezpośredniemu nadzorowi władzy, ma zatem potencjał wprowadzania w obowiązującą wizję rzeczywistości szkoły elementów sprzecznych z jej strukturą, co w konsekwencji może prowadzić do jej naruszenia, a nawet transformacji. Dyskurs opozycyjny jest zapośredniczony przez gesty, wypowiedzi oraz działania, które mogą mieć charakter transformujący lub reprodukujący panujący reżim dyskursywny w szkole. Niezależnie od intencji podmiotów opierających się, będących w pozycji nieuprzywilejowanej, może on przynieść niezamierzony efekt w postaci umacniana się struktur, które miały być podważone.

Kultura oporu, która ma charakter wywrotowy, wprowadza ryzyko w porządek szkoły. Brak całkowitej kontroli nad wszystkimi aspektami funkcjonowania uczniów w przestrzeni instytucji edukacyjnej stwarza sposobność do działań prowadzących do dysidentyfikacji (Rancière 1998), która polega na wyjściu poza przypisane role społeczne i szkolne. Wskazywał na to McLaren (1999), pisząc o uczniach, którzy przez większość pobytu w szkole pozostawali w „stanie ucznia”. Dla wielu z nich stan ten był uciążliwym gorsetem, krępującym ich ciała i umysły. $Z$ punktu widzenia instytucji edukacyjnej był to jednak stan najbardziej właściwy i odpowiedni, gdyż wprowadzał ład i harmonię w codzienność szkoły. „Stan uliczny” natomiast, typowy dla życia pozaszkolnego, zewnętrznego, występował w nielicznych i krótkich epizodach, które wydarzały się w codziennym życiu szkoły. Możliwość chwilowego przebywania w nim ma dla uczniów znaczenie katarktyczne. Za jego pośrednictwem mają oni siłę przetrwać w nieprzyjaznym środowisku szkolnym. Wejście w „stan uliczny” stwarza możliwość kreowania pewnej części uprzywilejowanego dyskursu, a także podważania nadprzyrodzoności i stałości jego fundamentów. W tym aspekcie słabi stają się chwilowo silni i upełnomocnieni do partycypacji w formowaniu istniejącego porządku aksjonormatywnego.

\section{Uczniowskie style adaptacji}

Wieloletnie doświadczenie szkolne i przedszkolne sprawia, że uczniowie wypracowują określone sposoby przystosowania się do tej ujarzmiającej instytucji. Część przyjmuje postawę konformistyczną i stara się sprostać regułom gry określonym przez kulturę dominującą. Jest to jeden $\mathrm{z}$ najbardziej rozpowszechnionych sposobów przystosowania się, o których pisał Merton (2002). W niniejszym artykule taki typ adaptacji określam mianem insiderskiego.

Część uczniów wybiera drogę zupełnie odmienną i otwarcie sprzeciwia się wartościom, celom, funkcjom i pozycjom wyznaczonym im przez szkołę. Do tej grupy należą uczniowie przejawiający styl wycofany, a także niektórzy buntownicy i rytualiści, sprzeciwiający się obowiązującym regułom. Reprezentanci tej grupy często wypadają z gry i tym samym potwierdzają konieczność istnienia danego ładu. Są to uczniowie, których 
określam mianem outsiderów, ponieważ ich działania opozycyjne nie prowadzą do zmiany istniejącego porządku, lecz do jego reprodukcji.

Kolejnym sposobem przystosowania się wskazanym przez Mertona (2002: 205) jest innowacja. W tego typu działaniach, również wynikających z motywacji buntowniczych, upatruję potencjał do działań subwersyjnych. Jest to sposób adaptacji, który nie wyraża zgody na obowiązujące reguły gry. Jednak podejmowane działania mają charakter wywrotowy, a nie przewrotowy. Ich celem są zmiana i transformacja, a nie zniszczenie ujarzmiających struktur.

Najliczniejszą grupę w szkole stanowią uczniowie, których określam mianem insiderów. Są oni konformistami, którzy przyjmują narzuconą im rzeczywistość i strukturę oraz podział ról społecznych. Mogą sporadycznie przejawiać działania nonkonformistyczne, lecz będą one wynikiem nonkonformizmu pozornego (Bernacka 2017: 34). Charakterystycznym typem tożsamości tych uczniów jest tożsamość legitymizująca, która jest wytwarzana przez dominujące instytucje społeczne, także przez szkołę (Castells 2009: 23). Insiderzy podejmują działania o charakterze mimikry lub emulacji (Szkudlarek 2009: 169), aby czuć się bezpiecznie w szkole oraz osiągnąć kulturowo zdefiniowane cele. W celu przetrwania trudnych sytuacji stosują strategię "martwego żuka” (Klus-Stańska 2012: 32), która polega na petryfikacji i nierzucaniu się w oczy potencjalnego napastnika, w tym wypadku - nauczyciela. Typowym przykładem tego sposobu adaptacji są działania podejmowane przez uczniów określanych w żargonie szkolnym jako „lizusi” i „kujoni”.

Outsiderzy wypracowali kolejny sposób przystosowania, a właściwie nieprzystosowania się do realiów życia szkoły. Uczniowie ci otwarcie i nierzadko dramatycznie manifestują swój sprzeciw wobec reguł tworzących szkolną rzeczywistość. Często są określani jako: „sprawiający trudności wychowawcze”, „,niegrzeczni”, „,niedostosowani”. Z tej grupy pochodzi tzw. odpad szkolny, czyli uczniowie, którzy przedwcześnie kończą naukę - nierzadko jest to pokłosiem nabytych w szkole, a niekiedy nawet już w przedszkolu, etykiet „głupka”, „półgłówka”, ,nieroba”. Podejmowane przez outsiderów działania nonkonformistyczne mają charakter destrukcyjny (Bernacka 2017: 33), ponieważ buntując się mniej lub bardziej świadomie przeciwko ujarzmiającym strukturom, paradoksalnie je reprodukują. W tym wypadku adekwatny jest klasyczny już cytat autorstwa Paula Willisa (1977: 1): „Working class kids get working class job”. Dla tych uczniów typowe są: tożsamość oporu w znaczeniu, jakie zaproponował Castells (2009), i działania bazujące na oporze, niekoniecznie na odporze (Rutkowiak 2012: 214).

Sposobem adaptacji do kultury szkoły najczęściej występującym w przestrzeni kultury oporu jest styl subwersiderski. Subwersiderzy podejmują działania o potencjale wywrotowym. Przejawiany przez nich o(d)pór bazuje na ustalonych normach, symbolach i narzuconych znaczeniach oraz ich interpretacjach. Takimi działaniami dokonują oni transformacji uznanych symboli i zmiany ich rozumienia. Przy użyciu różnych taktyk (Certeau 2008) „pogrywają” oni z władzą i dominacją, co prowadzi do zaistnienia w przestrzeni publicznego dyskursu elementów dyskursu ukrytego, niesłyszalnego lub określanego 
mianem niesemantycznego hałasu (Rancière 2007). Tego typu działania o(d)porowe mają potencjał emancypacyjny. Służą rozwojowi podmiotu oraz przekształcaniu spetryfikowanej struktury szkoły. Działając na obrzeżach kultury dominującej szkoły, subwersiderzy nie wypadają z niej, lecz stają się kreatorami zmian, ponieważ wprowadzają w jej obręb elementy antystruktury (Turner 2010). Paradoksalnie „słabi” stają się tu silnymi, ponieważ wyznaczają kierunek dyskursu szkolnego. Dla subwersiderów typowa jest tożsamość projektu (Castells 2009). Podejmowane przez nich działania nonkonformistyczne mają charakter konstruktywny (Bernacka 2017) i polegają na interwencjach w dominującą kulturę szkoły. Specyfika praktyk subwersyjnych przejawia się w tym, że wymykają się one istniejącej opozycji: kultura dominująca - kultura oporu (Skórzyńska 2010). Wywrotowość wyraża się w formach zawoalowanej krytyki kultury lub postulowanej przez Butler (2008) krytyki immanentnej. Nietypowość tej ostatniej polega na tym, że jest ona prowadzona z samego środka dyskursu, którego dotyczy. Działania oporowe są uświadomione i celowe, a ich specyfika i dynamika zależą od kontekstu.

Opór jest tu procesem zorientowanym na kwestionowanie „(...) zewnętrznie określonych znaczeń jako podstawy konstrukcji własnej tożsamości, tak aby uczynić ją inną od tej, która definiowana jest przez znaczenia narzucane przez dominującą kulturę" (Szkudlarek 2009: 169). Opór często ma tu znaczenie katarktyczne. Jest działaniem codziennym, subtelnym, które nie zawsze jest dostrzegane i rozumiane przez „nie-swoich”. To element jednoczący tych, którzy się opierają. Przykładem subwersyjnego stylu adaptacji jest postać błazna klasowego. Za pośrednictwem satyry, metafory lub parafrazy ukazuje on rzeczywistość szkolną w krzywym zwierciadle (Babicka-Wirkus 2019), dając tym samym bodziec nauczycielom i innym uczniom do spojrzenia na nią z innej perspektywy.

\section{Wielowymiarowość oporu a style adaptacji uczniów}

Analizowane sposoby adaptowania się uczniów do kultury szkoły można rozmieścić w różnych wymiarach jej funkcjonowania. $Z$ perspektywy kultury oporu będą mnie interesować szczególnie dwa style: outsiderski i subwersiderski, ponieważ mieszczą się one w wyznaczonych przez tę kulturę ramach. Insiderzy natomiast działają głównie w strukturach stworzonych przez kulturę dominującą i podlegają określonym przez nią regułom.

Kultura oporu w szkole posiada trzy wymiary: działan, motywacji i przestrzeni. Ich wzajemne przenikanie się tworzy specyficzną i dynamiczną strukturę, złożoną z polaryzacji (Babicka-Wirkus 2018b). Odwołując się do stworzonego przeze mnie trójwymiarowego modelu oporu (Babicka-Wirkus 2019: 49-52), chciałabym pokazać, w jaki sposób rozmieszczone są działania typowe dla outsiderów i subwersiderów w poszczególnych wymiarach tego zjawiska. Zabieg ten jest ważny dla zrozumienia specyfiki i znaczenia poszczególnych stylów adaptacji dla rozwoju ucznia i przemian rzeczywistości szkoły.

Dokładne omówienie poszczególnych sposobów adaptacji wykracza poza ramy tego opracowania, dlatego też dokonam tu wyłącznie zarysu, aby uchwycić ich złożoność. Uczniowie prezentujący styl outsiderski podejmują działania o charakterze dramatycznym, 
Tabela 1. Wymiary oporu a sposoby adaptacji uczniów

\begin{tabular}{|l|l|l|}
\hline \multirow{4}{*}{ Wymiar } & \multicolumn{1}{|c|}{ Outsiderzy } & \multicolumn{1}{c|}{ Subwersiderzy } \\
\cline { 2 - 3 } & \multicolumn{1}{|c|}{ polaryzacje } \\
\hline \multirow{5}{*}{ działania } & dramatyczne & subtelne \\
\cline { 2 - 3 } & indywidualne & zbiorowe \\
\cline { 2 - 3 } & przemocowe & pokojowe \\
\cline { 2 - 3 } motywacje & jawne & ukryte \\
\cline { 2 - 3 } & instrumentalne & ekspresyjne \\
\hline & nieuświadomione & uświadomione \\
\cline { 2 - 3 } & przeciw zmianie & dążenie do zmiany \\
\cline { 2 - 3 } & wolność od & wolność do \\
\cline { 2 - 3 } & zabieranie głosu - milczenie & \\
\hline \multirow{5}{*}{ przestrzeń } & profanum - sacrum & prospołeczna \\
\cline { 2 - 3 } & antyspołeczna & polityczna \\
\cline { 2 - 3 } & prepolityczna & produkcji \\
\cline { 2 - 3 } & reprezentacji & przeciwko władzy \\
\cline { 2 - 3 } & za władzą & \\
\hline
\end{tabular}

Źródło: opracowanie własne.

widowiskowym. Ich opór jest łatwo rozpoznawalny. Tego typu działania są domeną indywiduów klasowych, którzy poprzez ostentacyjne gesty, pozy, miny chcą wyrazić swój sprzeciw. Ich aktywność może przybierać formy przemocowe, poczynając od wyzwisk, wulgaryzmów, przez szyderczy śmiech, niecenzuralne rysunki i napisy niszczące mienie szkoły, na aktach fizycznej agresji kończąc. Przejawiane formy niezgody mają charakter instrumentalny i zmierzają do osiągnięcia pewnego celu, którym często jest zaburzenie toku lekcji. Takie działanie nie bazuje na krytycznym namyśle nad otaczającą ucznia rzeczywistością, lecz na potrzebie wyrażenia swojego znudzenia lub dokuczenia nauczycielowi.

Działania outsiderów, kiedy przyglądamy się im przez pryzmat wymiaru motywacji, są zazwyczaj nieuświadomione i nastawione na zapobieganie wszelkim zmianom oswojonej codzienności. Wynikają one z wolności negatywnej, w której uczeń upatruje źródła bezgranicznej swobody i braku odpowiedzialności moralnej za swoje czyny. Mogą one polegać zarówno na zabieraniu głosu, jak i na milczeniu. W obydwu wypadkach występuje brak pogłębionej refleksji nad zaistniałą sytuacją. Zabranie głosu i milczenie stanowią wyraz buty, a nie przejaw moralnej niezgody.

Trudno jednoznacznie wskazać przestrzeń, w której działają outsiderzy. Sfery święta i świecka są przez nich wykorzystywane w różnym stopniu. Jednak w odróżnieniu od subwersiderów outsiderom brakuje krytycznej refleksji nad celem wykorzystania obu tych przestrzeni. Problem staje się jeszcze istotniejszy, gdy weźmiemy pod uwagę, że 
uczniowie stosujący oba sposoby przystosowania się do szkoły wykorzystują swoje ciało jako narzędzie oporu. Ciało, będąc sferą profanum, może się przybliżać do świętości jedynie przez praktyki dyscyplinujące jego naturalne potrzeby i pragnienia.

Działania outsiderów są osadzone w przestrzeni antyspołecznej i prepolitycznej. „Opór występujący w przestrzeni antyspołecznej zazwyczaj prowadzi do zaognienia konfliktu [między nauczycielem a uczniem - A.B.W.]. Nastawiony jest raczej na unikanie występujących ograniczeń niż na podjęcie walki o zmianę rzeczywistości” (Babicka-Wirkus 2019: 46). Outsiderzy działają w sferze reprezentacji, ponieważ posługują się ustanowionym przez hegemoniczne struktury kodem i nieświadomie go reprodukują, a tym samym wpisują się w działania zmierzające do podtrzymania legitymizacji istniejącej władzy.

Opór przejawiany przez subwersiderów osadza się na przeciwstawnych krańcach kontinuów do tych, które są typowe dla outsiderskiego stylu adaptacji. Działania wywrotowców są subtelne i zazwyczaj przyjmują charakter zbiorowy, ponieważ wymagają współpracy. Są to aktywności pokojowe, które z powodu braku ostentacyjności nie są łatwe do uchwycenia. Nierzadko polegają na nieprzypadkowej grze symboli, kontekstów i znaczeń, jakie występują w konkretnej sytuacji. Bardzo często są to niepozorne gesty, pozy, uśmiechy, które trudno „wyłowić” ze schematu codziennego szkolnego porządku.

Dla subwersiderów opór ma znaczenie transformacyjne. Jest wyrazem ich moralnej niezgody i sprzeciwu. Podejmowane działania są uświadomione i mają na celu radzenie sobie z otaczającą rzeczywistością (Rutkowiak 2012: 214). Subwersiderzy, stawiając odpór nieakceptowanym aspektom szkoły, realizują przy tym swoje prawo do wolności, która rozumiana jest tu pozytywnie. Podobnie jak w wypadku outsiderów, subwersiderzy mogą działać przez zabieranie głosu lub milczenie. W każdym wypadku wybrana droga będzie miała jasno określony cel.

W wymiarze przestrzennym kultury oporu subwersiderzy działają zarówno w sferze sacrum, jak i profanum. Używają obu przestrzeni w spektakularny sposób (Courpasson, Vallas 2016: 9) w tym znaczeniu, że przestrzeń ujarzmiającego dyskursu zostaje zawłaszczona przez dyskurs odmienny, dyskurs tworzony przez „słabych”. Działania odporowe subwersiderów dokonują się w przestrzeni prospołecznej i politycznej, ponieważ mają charakter transformacyjny. Ich celem jest produkcja nowych, niedostrzegalnych znaczeń, symboli i interpretacji. Jest to opór, który narusza struktury władzy.

\section{Konkluzje}

Przeanalizowana typologia stylów adaptowania się uczniów do rzeczywistości szkoły odnosi się do wszystkich poziomów edukacji. Jednak praca nad budową indywidualnego sposobu adaptacji zaczyna się już na etapie edukacji przedszkolnej, gdzie dzieci są przygotowywane lub wręcz tresowane (Gawlicz 2014: 153) do życia szkolnego. Uczeń, rozpoczynając naukę w szkole podstawowej, powinien znać spetryfikowane reguły w niej panujące (Gawlicz 2014; Klus-Stańska 2014). W znacznej mierze jednak to od wczesnych doświadczeń edukacyjnych zależy, czy dziecko będzie się tym zasadom biernie podpo- 
rządkowywało, kierując się regułą „bądź posłuszny, bo zbłądzisz” (Klus-Stańska 2012: 24), czy też będzie je kontestowało.

Wczesne doświadczenia (anty-)edukacji instytucjonalnej kształtowane są przez dominującą kulturę szkoły (por. Gawlicz 2014). Jej zadaniem jest stanie na straży porządku społecznego i jego reprodukowanie. W tym aspekcie szkoła, a także przedszkole są instytucjami totalnymi (Goffman 2011) oraz normalizującymi (Foucault 2009). To społeczne instrumenty wywierania przymusu na indywidualne sposoby postępowania oraz interpretowania rzeczywistości społecznej (Skąpska, Ziółkowski 1998: 318). Paradoksalnie ten ujarzmiający charakter szkoły i przedszkola stwarza jednocześnie przestrzeń do kontestacji, do występowania działań o charakterze oporowym. Istotne jest, aby nauczyciele potrafili refleksyjnie kreować rzeczywistość doświadczeń klasowych i szkolnych, aby zachęcać dzieci do oporu subwersyjnego, a nie outsiderskiego.

Umiejętne przygotowanie dziecka do przejawiania oporu o potencjale wyzwalającym powinno się zaczynać od najwcześniejszych etapów edukacji. Jest to zadanie spoczywające na nauczycielach edukacji przedszkolnej i wczesnoszkolnej, którzy przede wszystkim powinni szanować podmiotowość dziecka i stwarzać mu przyjazne warunki do swobodnej ekspresji siebie i ujawniania swoich opinii (Babicka-Wirkus, Groenwald 2018).

\section{Literatura}

Babicka-Wirkus A. (2018a), Respektowanie prawa do autoekspresji a rytuaty oporu gimnazjalistów. Warszawa, Biblioteka Rzecznika Praw Dziecka.

Babicka-Wirkus A. (2018b), A Three-dimensional Model of Resistance in Education. „The New Educational Review", 52(2).

Babicka-Wirkus A. (2019), Kultury oporu w szkole. Działania-motywacje-przestrzeń. Warszawa, Wolters Kluwer.

Babicka-Wirkus A., Groenwald M. (2018), Gtos dziecka w przedszkolu-między swoboda wypowiedzi a milczeniem. „Problemy Wczesnej Edukacji”, 1(40).

Bernacka R.E. (2017), Predyktory nonkonformizmu pozornego. Lublin, Wydawnictwo Uniwersytetu Marii Curie-Skłodowskiej.

Bilińska-Suchanek E. (2003), Opór wobec szkoły. Dorastanie w perspektywie paradygmatu oporu. Kraków, Oficyna Wydawnicza „Impuls”.

Butler J. (2008), Uwikłani w płeć. Warszawa, Wydawnictwo Krytyki Politycznej.

Castells M. (2009), Siła tożsamości. Warszawa, Wydawnictwo Naukowe PWN.

Certeau M. de (2008), Wynaleźć codzienność. Sztuki działania. Kraków, Wydawnictwo Uniwersytetu Jagiellońskiego.

Courpasson D., Vallas S. (2016), Resistance Studies: A Critical Introduction. W: D. Courpasson, S. Vallas (ed.), The SAGE Handbook of Resistance. Los Angeles - London - New Delhi - Singapore - Washington DC - Melbourne, SAGE Reference.

Foucault M. (2009), Nadzorować i karać. Narodziny więzienia. Warszawa, Wydawnictwo Aletheia.

Gawlicz K. (2014), Gotowi do podporzadkowania się. Edukacja przedszkolna jako proces kształtowania zdezintegrowanych podmiotów. W: D. Klus-Stańska (red.), (Anty)edukacja wczesnoszkolna. Kraków, Oficyna Wydawnicza „Impuls”. 
Goffman E. (2011), Instytucje totalne. O pacjentach szpitali psychiatrycznych i mieszkańcach innych instytucji totalnych. Sopot, Gdańskie Wydawnictwo Psychologiczne.

Klus-Stańska D. (2012), Wiedza, która zniewala - transmisyjne tradycje w szkolnej edukacji. „Forum Oświatowe", 1(46).

Klus-Stańska D. (2014), Dezintegracja tożsamości i wiedzy jako proces $i$ efekt edukacji wczesnoszkolnej. W: D. Klus-Stańska (red.), (Anty)edukacja wczesnoszkolna. Kraków, Oficyna Wydawnicza „Impuls”.

Kuligowski W. (2012), Od „rytuałów buntu” do ,etnografii wojujacej”. Kategoria sprzeciwu w teorii antropologicznej. W: W. Kuligowski, A. Pomieciński (red.), Oblicza buntu. Praktyki i teorie sprzeciwu w kulturze wspótczesnej. Poznań, Wydawnictwo Poznańskie.

McLaren P. (1999), Schooling as a Ritual Performance. Toward a Political Economy of educational Symbols and Gestures. Lanham - Boulder - New York - Oxford, Rowman \& Littlefield.

McLaren P. (2015), Życie w szkołach. Wprowadzenie do pedagogiki krytycznej. Wrocław, Wydawnictwo Naukowe DSW.

Merton R. (2002), Teoria socjologiczna i struktura spoleczna. Warszawa, Wydawnictwo Naukowe PWN.

Rancière J. (1998), Dis-agreement. Politics and Philosophy. Minneapolis, University of Minneapolis.

Rancière J. (2007), Dzielenie postrzegalnego. Estetyka jako polityka. Kraków, Ha!art.

Rutkowiak J. (2012), Neoliberalizm jako kulturowy kontekst ksztattowania się tożsamości wspótczesnego nauczyciela. Ku problematyce oporu i odporu edukacyjnego. W: E. Potulicka, J. Rutkowiak, Neoliberalne uwikłania edukacji. Kraków, Oficyna Wydawnicza „Impuls”.

Scott J.C. (1985), Weapons of the Weak: Everyday Forms of Peasant Resistance. New Haven, Yale University Press.

Skąpska G., Ziółkowski M. (1998), Instytucja społeczna. W: Z. Bokszański (red.), Encyklopedia socjologii. T. 1. Warszawa, Oficyna Naukowa.

Skórzyńska A. (2010), Subwersje miejskie. Niewyraźne kultury oporu. „Kultura Współczesna”, 2(64).

Szkudlarek T. (2009), Wiedza i wolność w pedagogice amerykańskiego postmodernizmu. Kraków, Oficyna Wydawnicza „Impuls”.

Turner V. (2010), Proces rytualny. Warszawa, Państwowy Instytut Wydawniczy.

Willis P. (1977), Learning to Labor: How Working Class Kids Get Working Class Jobs. New York, Columbia University. 